Article

\title{
Carbonaceous Greenhouse Gases and Microbial Abundance in Paddy Soil under Combined Biochar and Rice Straw Amendment
}

\author{
Supitrada Kumputa ${ }^{1,2}$, Patma Vityakon ${ }^{1,2}$, Patcharee Saenjan ${ }^{1,2}$ and Phrueksa Lawongsa ${ }^{1,2, *}$ \\ 1 Department of Soil Science and Environment, Faculty of Agriculture, Khon Kaen University, \\ Khon Kaen 40002, Thailand; nokie_msu@hotmail.com (S.K.); patma@kku.ac.th (P.V.); \\ patsae1@kku.ac.th (P.S.) \\ 2 Soil Organic Matter Management Research Group, Department of Soil Science and Environment, Faculty of \\ Agriculture, Khon Kaen University, Khon Kaen 40002, Thailand \\ * Correspondence: phrula@kku.ac.th; Tel.: +66-43-364639
}

Received: 6 March 2019; Accepted: 30 April 2019; Published: 6 May 2019

check for updates

\begin{abstract}
Little is known about the carbonaceous greenhouse gases and soil microbial community linked to the combination of biochar (BC) and rice straw (RS) in paddy soils. The objectives of this research were to evaluate the effects of combining $\mathrm{BC}$ and $\mathrm{RS}$ on (1) $\mathrm{CH}_{4}$ and $\mathrm{CO}_{2}$ production from paddy soil, (2) archaeal and bacterial abundance, and (3) rice grain yield. The experiments consisted of a pot trial and an incubation trial, which had a completely randomized design. The experiments included five treatments with three replications: (a) the control (without BC, RS, and chemical fertilizer (CF)); (b) CF; (c) BC $12.50 \mathrm{t} \mathrm{ha}^{-1}$; (d) RS $12.50 \mathrm{t} \mathrm{ha}^{-1}$; and (e) combined BC $6.25 \mathrm{t} \mathrm{ha}^{-1}+\mathrm{RS} 6.25 \mathrm{t}$ $\mathrm{ha}^{-1}+\mathrm{CF}$. In the sole RS treatment, $\mathrm{CH}_{4}$ production $\left(0.0347 \mathrm{mg} \mathrm{m}^{-2}\right.$ season $\left.{ }^{-1}\right)$ and the archaeal and bacterial abundance $\left(5.81 \times 10^{8}\right.$ and $4.94 \times 10^{10}$ copies $^{-1}$ soil dry weight (DW)) were higher than outcomes in the sole BC treatment (i.e., $0.0233 \mathrm{mg} \mathrm{m}^{-2}$ season ${ }^{-1}$ for $\mathrm{CH}_{4}$ production, and 8.51 $\times 10^{7}$ and $1.76 \times 10^{10}$ copies $\mathrm{g}^{-1}$ soil DW for archaeal and bacterial abundance, respectively). $\mathrm{CH}_{4}$ production $\left(0.0235 \mathrm{mg} \mathrm{m}^{-2}\right.$ season $\left.{ }^{-1}\right)$ decreased significantly in the combined $\mathrm{BC}+\mathrm{RS}+\mathrm{CF}$ treated soil compared to the soil treated with $\mathrm{RS}$ alone, indicating that $\mathrm{BC}$ lessened $\mathrm{CH}_{4}$ production via $\mathrm{CH}_{4}$ adsorption, methanogenic activity inhibition, and microbial $\mathrm{CH}_{4}$ oxidation through bacterial

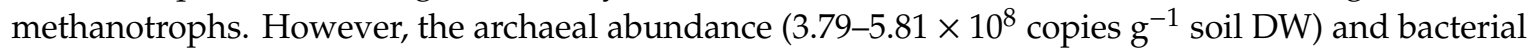
abundance $\left(4.94-5.82 \times 10^{10}\right.$ copies $^{-1}$ soil DW) in the combined BC+ RS + CF treated soil and the RS treated soil were found to increase relative to the treatments without RS. The increase was due to the easily decomposable RS and the volatile matter (VM) constituent of the BC. Nevertheless, the resultant $\mathrm{CO}_{2}$ production was relatively similar amongst the $\mathrm{BC}, \mathrm{RS}$, and $\mathrm{BC}+\mathrm{RS}$ treated soils, which was indicative of several processes, e.g., the $\mathrm{CO}_{2}$ production and reduction that occurred simultaneously but in different directions. Moreover, the highest yield of rice grains was obtained from a combined BC + RS + CF treated soil and it was $53.47 \mathrm{~g} \mathrm{pot}^{-1}\left(8.48 \mathrm{t} \mathrm{ha}^{-1}\right)$. Over time, the addition of $\mathrm{BC}$ to RS soil enhanced the archaeal and bacterial abundance, thereby improving yields and reducing $\mathrm{CH}_{4}$ emissions.
\end{abstract}

Keywords: global warming; archaeal $16 \mathrm{~S}$ rRNA gene; bacterial $16 \mathrm{~S}$ rRNA gene; rice yields; qPCR; soil amendments

\section{Introduction}

To maintain the soil fertility and rice yield, the incorporation of rice straw (RS) into paddy soil has been widely practiced. However, in flooded soil conditions, the decomposition of RS results in high levels of $\mathrm{CH}_{4}$ and $\mathrm{CO}_{2}$ emissions from its high cellulose and hemicellulose content (at more than $50 \%$ 
dry weight), both of which are easily decomposable $C$ compounds [1]. In addition, some intermediate $C$ products include dissolved organic carbon (DOC), which comprises low molecular-weight organic compounds such as acetates, formates, methylated compounds, primary and secondary alcohols, and some gases, e.g., $\mathrm{CO}_{2}$ and $\mathrm{H}_{2}$. All of these compounds are substrates for the methanogenic archaea which stimulate $\mathrm{CH}_{4}$ production [2]. Concurrently, $\mathrm{CH}_{4}$ oxidation mediated by methanotrophic microorganisms existing in the flooded soil system also occurs. The $\mathrm{CH}_{4}$ oxidation results in the production of $\mathrm{CO}_{2}$, as well as a decrease in $\mathrm{CH}_{4}$ emissions into the atmosphere.

Contrary to the easily decomposable RS, biochar (BC), which is made from woody feedstock materials, has high contents of $C$ resistant compounds, such as lignin [1]. Therefore, it is considered to be a resistant organic material. In particular, eucalyptus wood BC contains over $70 \%$ lignin (DW), which suppresses microbially mediated $C$ mineralization $[1,3]$. The addition of $B C$ creates a low available $\mathrm{C}$ condition, creating unsuitable circumstances for methanogenesis by archaea [4]. Although the BC incorporated into paddy soils suppresses $\mathrm{CH}_{4}$ emissions, it also increases nutrient availability and rice yields [3]. When $\mathrm{RS}$ and $\mathrm{BC}$ were individually applied to paddy soils, contrasting effects on $\mathrm{CH}_{4}$ production were found. Owing to contrasting chemical compositions, RS produced enhancing effects, whereas BC produced suppressing effects given its high content of fixed C, such as lignin [3], which are unfavorable to methanogenic activity [5]. Nevertheless, it is worth studying the incorporation of combined BC with RS, as well as the biological aspects of methanogen. In field situations, when BC is applied to paddy soil, it inevitably mixes with RS residues that remain after the paddy fields have been harvested. Therefore, it is imperative to investigate the effects of combining BC and RS on greenhouse gas production. An earlier study by Liu et al. [5] showed that when medium to high amounts of rice straw derived $\mathrm{BC}$ were mixed with $\mathrm{RS}$, the $\mathrm{CH}_{4}$ emissions from the incubated paddy soils declined by $21-35 \%$ compared to emissions without $\mathrm{BC}$, citing the inhibiting effect of $\mathrm{BC}$ on methanogenic activity. However, the study did not investigate the microbial abundance. Findings on methanogen stimulation by $\mathrm{BC}$ were later reported by Feng et al. [6], who employed microbial gene abundance as the main indicator of microbial influence on $\mathrm{CH}_{4}$ emissions in soils treated solely with $\mathrm{BC}$. The research showed that corn stalk BC stimulated both the methanogenic archaea and the methanotrophic bacteria, as determined by their gene abundances. However, the $\mathrm{CH}_{4}$ produced by the archaea could not meet the requirements of the bacteria. To our knowledge, there is no known work which has combined easily decomposable RS and resistant eucalyptus BC to test the effects of this mixture on the production of $\mathrm{CH}_{4}$ and other carbonaceous greenhouse gases, using microbial gene abundance as a major indicator.

In this research, we addressed the hypothesis that adding the combined $\mathrm{BC}$ and RS to a paddy soil would reduce the soil's $\mathrm{CH}_{4}$ production, raise its archaeal and bacterial abundance, and increase the rice grain yields. Therefore, the objectives of this research were as follows: (i) To evaluate the effects of the combined $\mathrm{BC}$ and $\mathrm{RS}$ on $\mathrm{CH}_{4}$ production, $\mathrm{CO}_{2}$ production, and the archaeal and bacterial abundance in paddy soils and (ii) to determine the effects that these conditions would have on the rice grain yields.

\section{Materials and Methods}

\subsection{Organic Materials and Soil}

$\mathrm{BC}$ was produced via pyrolysis at $350^{\circ} \mathrm{C}$ under oxygen limited conditions in a traditional kiln commonly used in Northeastern Thailand. The feedstock consisted of the upper parts of the branches of 5 year-old eucalyptus trees (Eucalyptus camaldulensis Dehnh.). Meanwhile, the RS used was taken from a paddy field. The following chemical analyses of the BC and RS were conducted: (1) $\mathrm{pH}$ using a pH meter (BC or RS: water =1:5); (2) total organic carbon content using a TOC Analyzer (multi EA 4000, Analytik Jena, Jena, Germany); (3) total nitrogen using the micro-Kjeldahl method [7]; (4) the content of cellulose, hemicellulose, and lignin in the RS and BC as described by Aravantinos-Zafiris et al. [8]; (5) the content of ash, VM, and fixed C in the BC, based on the American standard test method [9]; and 
the functional groups on the surface of the BC and RS were analyzed using Fourier transform infrared (FTIR) spectroscopy (TENSOR27, Bruker, Germany), at frequency ranges from 600 to $4000 \mathrm{~cm}^{-1}$.

The chemical characteristics of the BC and RS are shown in Table 1

Table 1. Characteristics of the BC and RS used in the experiments.

\begin{tabular}{|c|c|c|c|c|c|c|c|c|c|c|}
\hline \multirow{2}{*}{$\begin{array}{c}\text { Organic } \\
\text { Materials }^{1}\end{array}$} & \multirow{2}{*}{$\begin{array}{c}\mathrm{pH} \\
(1: 5)\end{array}$} & $\mathrm{OC}^{2}$ & $\mathrm{TN}^{3} \mathrm{TN}$ & \multirow[t]{2}{*}{$\begin{array}{l}\mathrm{C} / \mathrm{N}^{4} \\
\text { Ratio }\end{array}$} & \multirow[t]{2}{*}{ Cellulose } & \multirow[t]{2}{*}{ Hemicell $^{5}$} & \multirow[t]{2}{*}{ Lignin } & \multirow[t]{2}{*}{ Fixed C } & \multirow[t]{2}{*}{ Ash } & \multirow[t]{2}{*}{$\mathrm{VM}^{6}$} \\
\hline & & & $\%$ & & & & & & & \\
\hline BC & 6.32 & 60.2 & 0.56 & 101 & 1.24 & 1.65 & 75.69 & 61.72 & 3.3 & 34.97 \\
\hline RS & 7.47 & 40.9 & 0.43 & 95 & 46.65 & 22.17 & 7.11 & - & - & - \\
\hline
\end{tabular}

${ }^{1} \mathrm{BC}=$ biochar, $\mathrm{RS}=$ rice straw $;{ }^{2} \mathrm{OC}=$ organic carbon; ${ }^{3} \mathrm{TN}=$ total nitrogen $;{ }^{4} \mathrm{C} / \mathrm{N}=$ carbon $/$ nitrogen $;{ }^{5}$ Hemicell $=$ hemicellulose; ${ }^{6} \mathrm{VM}=$ volatile matter.

The BC FTIR spectra contained the following peaks (Figure 1a): $3570-3200 \mathrm{~cm}^{-1}$ (hydroxy group); $2921 \mathrm{~cm}^{-1}$ (methylene C-H asymmetric); 1928-2113 $\mathrm{cm}^{-1}$ (aromatic combination bands) [10]; $1641-1737 \mathrm{~cm}^{-1}$ (C=O of aromatic group) [11]; 1373 and $1591 \mathrm{~cm}^{-1}$ (carboxylate); and $1205 \mathrm{~cm}^{-1}$ (phenol, C-O stretch) [10]. The RS spectra (Figure 1b) contained a $3570-3200 \mathrm{~cm}^{-1}$ (hydroxy group); $1637 \mathrm{~cm}^{-1}$ (carboxylate); and $1033 \mathrm{~cm}^{-1}$ (aromatic C-H in plane bend) [10].
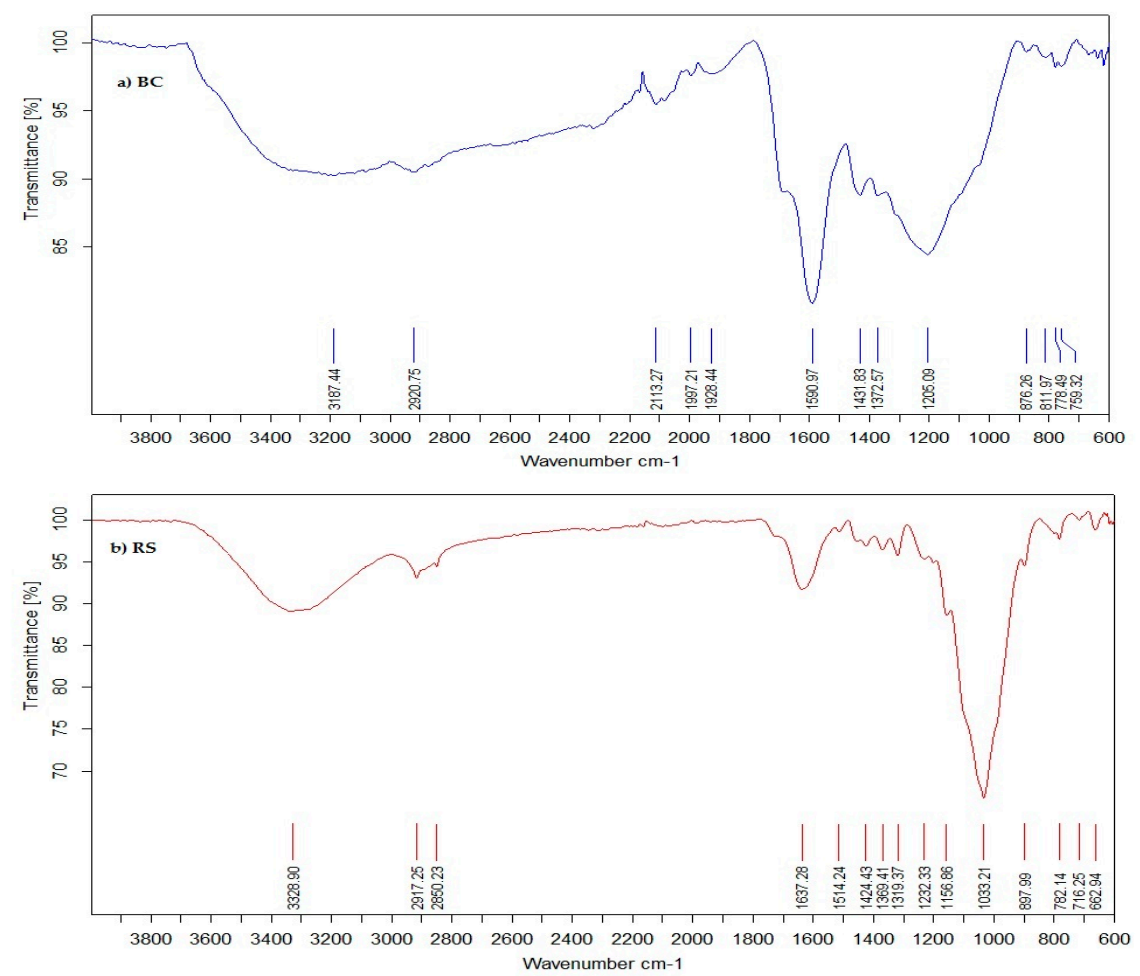

Figure 1. Fourier transform infrared (FTIR) spectra of the biochar (BC) (a) and rice straw (RS) (b) used in the experiments.

Paddy soil samples were randomly collected from the plow layer $(0-15 \mathrm{~cm})$ of an irrigated paddy field located in Ban Na Ngam in the Samran District of Khon Kaen, Thailand (N 16 $32^{\prime} 45.9^{\prime \prime}$, E $\left.102^{\circ} 51^{\prime} 15.5^{\prime \prime}\right)$. The soil was classified as fine, mixed, and isohyperthermic Aeric Endoaquept. The soil was air-dried and then finely ground to be able to pass through a $2 \mathrm{~mm}$ sieve. The physical and chemical characteristics of the soil were analyzed for: (1) the soil texture using the hydrometer method [12]; (2) the soil organic carbon contents using wet digestion [13]; and (3) the total nitrogen using the micro-Kjeldalh method [7]. The soil showed the following physical-chemical properties: $\mathrm{pH}$ 
$(1: 5)=5.06$; sandy loam texture with sand $(65.8 \%)$; silt $(21.9 \%)$; and clay $(12.4 \%)$ with a soil organic carbon content of $0.83 \%$ and a nitrogen content of $0.08 \%$.

\subsection{Experiments}

Two experiments (i.e., a pot and an incubation experiment) were conducted. The pot experiment was designed to evaluate the effects of the combined BC and RS on the production of carbonaceous gases, the microbial biomass, and the rice yields under non-leaching controlled conditions in the presence of rice plants. In contrast, the incubation experiment was designed to support the biological and biochemical data collected from homogeneous non-living root soils, to examine the effects of the combined BC and RS.

\subsubsection{Pot Experiment}

The pot experiment was performed from June to October 2015 in a greenhouse located at the Faculty of Agriculture at the Khon Kaen University in Khon Kaen, Thailand. Five treatments, performed in triplicate, were included as follows: (1) the control (without CF, BC, and RS amendments); (2) CF grade 16-16-8 [Urea $(46 \% \mathrm{~N}),\left(\mathrm{NH}_{4}\right)_{2} \mathrm{HPO}_{4}\left(18 \% \mathrm{~N}, 46 \% \mathrm{P}_{2} \mathrm{O}_{5}\right), \mathrm{KCl}\left(60 \% \mathrm{~K}_{2} \mathrm{O}\right)$ ] at a rate of $0.188 \mathrm{tha}^{-1}$ as modified from the study by Thammasom et al. [3]; (3) BC $12.50 \mathrm{t} \mathrm{ha}^{-1}$; (4) RS $12.50 \mathrm{t} \mathrm{ha}^{-1}$; and (5) a mixture of BC:RS (1:1 w/w at a rate of $6.25 \mathrm{t} \mathrm{ha}^{-1}$ each) and CF. The experiment was arranged using a completely randomized design, wherein three kgs of sieved air-dried soil was placed in a pot (inner dimensions of $18 \mathrm{~cm}$ and a height of $23 \mathrm{~cm}$, without a hole at the bottom). Based on the treatment parameters, the soil was then mixed with $2 \mathrm{~mm}$ sieved BC and/or RS (cut to a size of $2 \mathrm{~cm}$ in length). The soils in all the pots were submerged for 20 days before transplanting. This procedure was carried out to allow time for decomposition, so that the adverse effects from the toxic intermediate organic acid products of decomposition could be avoided. Then, three rice (Oryza sativa L.) seedlings ( 25 days old) of the Pitsanulok 2 (a photoperiod insensitive) varieties were transplanted to each pot. The CF was basally applied twice, that is, before transplanting and then 30 days after transplanting. Throughout the rice growing period, all the pots were maintained at a water level that was $5-7 \mathrm{~cm}$ above the soil surface without leaching, and the water was drained 10 days prior to the rice harvest.

\subsubsection{Incubation Experiment}

Treatments for the incubation trials were similar to the pot experiment treatments. Soil $(2.5 \mathrm{~g})$ was placed into a $60 \mathrm{~mL}$ glass bottle and then mixed with $2 \mathrm{~mm} \mathrm{BC}$ and/or RS based on the treatments. Thereafter, $10 \mathrm{~mL}$ of the $\mathrm{CF}$ solution of the same strength as that used in the pot experiment was applied to the soil mixture. Calculations of the BC and RS weights were based on a soil bulk density of $1.39 \mathrm{~g} \mathrm{~cm}^{-3}$ and a soil weight of $2085 \mathrm{t} \mathrm{ha}^{-1}$. The head space of the bottle was flushed with $\mathrm{N}_{2}$ gas $(99.99 \%)$, and then it was tightly closed using a septum and aluminum cap. The incubation of the soil was carried out at $28^{\circ} \mathrm{C}$ for a period of 14 days under anaerobic conditions. The incubation period (14-days) was determined based on our previous study which found the highest $\mathrm{CH}_{4}$ and $\mathrm{CO}_{2}$ emissions after 14 days of incubation.

\subsection{Data Collection}

\subsubsection{Rice Grain and Microbial Biomass $\mathrm{C}(\mathrm{MBC})$ in the Pot Experiment}

After harvesting, rice grains collected from each pot were dried in an oven at $75{ }^{\circ} \mathrm{C}$ for 48 hours, and then weighed. A fresh soil sample was taken from each pot and analyzed for the MBC using the chloroform fumigation-extraction method described in Reference [14].

\subsubsection{Gas Sampling, $\mathrm{CH}_{4}$, and $\mathrm{CO}_{2}$ Analysis in the Pot and Incubation Experiments}

In the pot experiment, gas samples were collected using the closed chamber method. We used a transparent chamber made from acrylic, that was sized $21 \times 21 \times 100 \mathrm{~cm}$ (width $\times$ length $\times$ height). Gas 
sampling was performed once a week throughout the rice growing period. The process was carried out between 9.00 and 11.00 a.m., and a $1 \mathrm{ml}$ insulin syringe was used to obtain the gas samples at 0,10 , and $20 \mathrm{~min}$ after the chamber cover had been placed over the potted soil as in Reference [15]. $\mathrm{CH}_{4}$ and $\mathrm{CO}_{2}$ concentrations were measured using a gas chromatograph (GC-2014, Shimadzu, Kyoto, Japan) equipped with a flame ionization detector (FID) as described in Reference [1]. The gas measurements were completed within 6 hours.

Under the incubation experiment, the $1 \mathrm{~mL}$ gas samples were collected 14 days after incubation from the head space of the glass bottles using a 1-mL insulin syringe. After collection, the $\mathrm{CH}_{4}$ and $\mathrm{CO}_{2}$ concentrations were immediately determined.

\subsection{DOC Analysis and Determination of Archaeal and Bacterial Abundance in the Incubation Experiment}

Extraction of DOC from the incubated soil was done by shaking the bottle for $30 \mathrm{~min}$, followed by centrifuging at $4000 \mathrm{rpm}$ for $15 \mathrm{~min}$. The supernatant solution was filtered through a $0.45 \mu \mathrm{m}$ syringe filter prior to the DOC analysis, using the TOC/TN $b$ analyzer (Multi N/C 2100s, Analytik Jena, Jena, Germany).

\subsection{DNA Extraction and Quantitative Polymerase Chain Reaction ( $q P C R$ )}

The total soil genomic DNA was extracted using a FastDNA ${ }^{\mathrm{TM}}$ SPIN Kit for Soil (MP Biomedicals, Santa Ana, CA, USA). The qPCR of the bacterial 16S rRNA gene and archaeal 16S rRNA gene were performed using a C1000 Touch ${ }^{\mathrm{TM}}$ thermal cycler combined with a CFX96 ${ }^{\mathrm{TM}}$ detection module (BIO-RAD, Hercules, CA, USA). The primers and annealing conditions are listed in Table 2. The PCR mixtures $(25 \mu \mathrm{L})$ contained $12.5 \mu \mathrm{L}$ of EXPRESS SYBR ${ }^{\circledR}$ GreenER $^{\mathrm{TM}}$ (Invitrogen, Carlsbad, CA, USA), $0.4 \mu \mathrm{M}$ primer (each; final concentration), $1 \mu \mathrm{L}$ of DNA template $\left(10 \mathrm{ng} \mu \mathrm{L}^{-1}\right)$, and ultrapure water for the balance. Moreover, all the samples were analyzed in triplicate. Each reaction condition included an initial denaturing step of $10 \mathrm{~min}$ at $95^{\circ} \mathrm{C}$, followed by 40 cycles of $30 \mathrm{~s}$ of denaturing at $95^{\circ} \mathrm{C}, 30 \mathrm{~s}$ of primer annealing (Table 2), and then $45 \mathrm{~s}$ of primer extension at $72{ }^{\circ} \mathrm{C}$. The annealing temperatures were optimized for each primer pair. The abundances of bacteria and archaea determined using qPCR were reported as DNA copy numbers of 16S rRNA genes per g of dry soil.

Table 2. The qPCR primers and conditions used in this study.

\begin{tabular}{clccc}
\hline Primers & \multicolumn{1}{c}{ Sequences $\left(\mathbf{5}^{\prime}\right.$ to $\left.\mathbf{3}^{\prime}\right)$} & Annealing Temps $\left({ }^{\circ} \mathbf{C}\right)$ & Targeted Groups & References \\
\hline Eub338 & ACCTACGGGAGGCAGCAG & 55 & Bacteria & {$[16]$} \\
Eub518 & ATTACCGCGGCTGCTGG & 55 & Bacteria & {$[17]$} \\
Ar109f & ACKGCTCAGTAACACGT & 57.5 & Archaea & {$[18]$} \\
Ar912r & CTCCCCCGCCAATTCCTTTA & 57.5 & Archaea & {$[18]$} \\
\hline
\end{tabular}

\subsection{Statistical Analysis}

One-way analysis of variance (ANOVA) was used to assess the treatment effects on various soil microbiological and biochemical properties, carbonaceous greenhouse gas emissions, and rice yields. Mean separation was performed using least significant difference (LSD) tests. We used the Statistix 10 software to carry out the statistical tests. To determine the correlation between the abundances of archaea and bacteria, the production of $\mathrm{CH}_{4}$ and $\mathrm{CO}_{2}$, and the DOC content in the incubated rice soil, the SigmaPlot 12.5 software program was used.

\section{Results and Discussion}

\subsection{Carbonaceous Greenhouse Gases and Microbial Abundance in Paddy Soil as Affected by RS}

Significant increases in the production of $\mathrm{CH}_{4}$ were observed in the soil amended with RS alone, and in both pots $\left(0.0347 \mathrm{mg} \mathrm{m}^{-2}\right.$ season ${ }^{-1}$ ) (Table 3) and incubation experiments (1379.3 $\mathrm{mg} \mathrm{kg}^{-1}$ ) (Table 4) relative to the other treatments. The increases in $\mathrm{CH}_{4}$ production were due to the high 
contents of easily decomposed cellulose (46.65\%) and hemicellulose $(22.17 \%)$ in the RS (Table 1). When the RS was applied to the soil, it had a key role in stimulating the soil's microbial activity for $\mathrm{C}$ mineralization. This was indicated by a significantly higher DOC content $\left(202.69 \mathrm{mg} \mathrm{kg}^{-1}\right)$, and

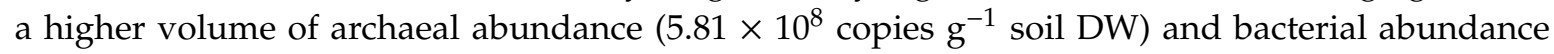
$\left(4.94 \times 10^{10}\right.$ copies $\mathrm{g}^{-1}$ soil DW) in the RS compared to other treatments, with the exception of the mixed RS + BC treatment (Table 4). Dissolved organic $C$ is a mixture of dissolved organic carbonaceous compounds with particle sizes that are smaller than $0.45 \mu \mathrm{m}$. It is derived from the degradation of organic materials and it contains carbohydrates, proteins, fats, hydrocarbons and their derivatives, and fractions of low molecular weight humic acids; as well as numerous simple organic compounds [19]. DOC is a crucial part of the organic labile pool which serves as substrates for soil microorganisms. Rice straw was found to generate a high content of low molecular weight DOC within two weeks after incorporation into the topsoil $(0-15 \mathrm{~cm})$ of a sandy soil from Northeastern Thailand [20]. During our 2-week incubation period, the soil treatments containing RS showed a higher abundance of archaea than the other treatments. Archaea was a dominant microbe that utilized the DOC, $\mathrm{CO}_{2}$, and $\mathrm{H}_{2}$ [21] from decomposing $\mathrm{RS}$ to produce $\mathrm{CH}_{4}$. This revealed the archaea's function in methanogenesis, which involved $\mathrm{CO}_{2}$ reduction.

Table 3. $\mathrm{CH}_{4}, \mathrm{CO}_{2}$ emissions, rice grains, and microbial biomass $\mathrm{C}(\mathrm{MBC})$ in the potted rice-soil treated with $\mathrm{BC}$ and RS.

\begin{tabular}{|c|c|c|c|c|}
\hline Treatments ${ }^{1}$ & $\begin{array}{c}\mathrm{CH}_{4} \\
\mathrm{mg} \mathrm{m}^{-2}\end{array}$ & $\begin{array}{c}\mathrm{CO}_{2} \\
\text { Season }^{-1}\end{array}$ & $\begin{array}{l}\text { Rice Grains } \\
\qquad \mathrm{g} \mathrm{pot}^{-1}\end{array}$ & $\begin{array}{c}\mathrm{MBC}^{2} \\
\mathrm{mg} \mathrm{kg}^{-1}\end{array}$ \\
\hline Control & $0.0298 \mathrm{ab}$ & $0.0018 \mathrm{~b}$ & $41.52 \mathrm{~b}$ & $79.81 \mathrm{c}$ \\
\hline $\mathrm{CF}$ & $0.0263 \mathrm{~b}$ & $0.0012 \mathrm{c}$ & $50.62 \mathrm{a}$ & $93.66 \mathrm{bc}$ \\
\hline BC $12.50 \mathrm{tha}^{-1}$ & $0.0233 \mathrm{~b}$ & $0.0013 \mathrm{c}$ & $35.55 \mathrm{~b}$ & $224.08 \mathrm{a}$ \\
\hline RS $12.50 \mathrm{tha}^{-1}$ & $0.0347 \mathrm{a}$ & $0.0021 \mathrm{a}$ & $35.43 \mathrm{~b}$ & $129.84 \mathrm{bc}$ \\
\hline BC $6.25 \mathrm{tha}^{-1}+\mathrm{RS} 6.25 \mathrm{tha}^{-1}+\mathrm{CF}$ & $0.0235 \mathrm{~b}$ & $0.0012 \mathrm{c}$ & $53.47 \mathrm{a}$ & $167.94 \mathrm{ab}$ \\
\hline F-test & $*$ & ** & $* *$ & $*$ \\
\hline $\mathrm{CV}(\%)$ & 15.87 & 2.99 & 7.00 & 33.26 \\
\hline
\end{tabular}

${ }^{1} \mathrm{CF}=$ chemical fertilizer, $\mathrm{BC}=$ biochar, $\mathrm{RS}=$ rice straw, $\mathrm{CV}=$ coefficient of variation. ${ }^{2} \mathrm{MBC}=$ microbial biomass carbon. The different small letters in the columns indicate significant difference among treatments by LSD. ${ }^{*}, * *=$ significant at $p \leq 0.05$ and $p \leq 0.01, \mathrm{n}=3$.

Table 4. The abundance of archaea and bacteria, $\mathrm{CH}_{4}$ and $\mathrm{CO}_{2}$ production, and DOC content in 14-day incubated soils treated with BC and RS.

\begin{tabular}{|c|c|c|c|c|c|}
\hline Treatments $^{1}$ & $\begin{array}{c}\text { Archaea } \\
\text { Copies } \mathbf{g}^{-1}\end{array}$ & $\begin{array}{l}\text { Bacteria } \\
\text { Soil DW }\end{array}$ & $\begin{array}{c}\mathrm{CH}_{4} \\
\mathrm{mg} \mathrm{kg}^{-1}\end{array}$ & $\begin{array}{c}\mathrm{CO}_{2} \\
\mathrm{mg} \mathrm{kg}^{-1}\end{array}$ & $\begin{array}{c}\mathrm{DOC}^{2} \\
\mathrm{mg} \mathrm{kg}^{-1}\end{array}$ \\
\hline Control & $1.21 \times 10^{8} \mathrm{~b}$ & $1.88 \times 10^{10} \mathrm{~b}$ & $61.6 \mathrm{~b}$ & 3459.7 a & $98.00 \mathrm{~b}$ \\
\hline CF & $6.73 \times 10^{7} \mathrm{~b}$ & $2.24 \times 10^{10} \mathrm{~b}$ & $32.6 \mathrm{~b}$ & $1730.4 \mathrm{~b}$ & $84.92 \mathrm{~b}$ \\
\hline BC $12.50 \mathrm{tha}^{-1}$ & $8.51 \times 10^{7} \mathrm{~b}$ & $1.76 \times 10^{10} \mathrm{~b}$ & $45.7 \mathrm{~b}$ & $229.3 c$ & $78.88 \mathrm{~b}$ \\
\hline RS $12.50 \mathrm{tha}^{-1}$ & $5.81 \times 10^{8} \mathrm{a}$ & $4.94 \times 10^{10} \mathrm{a}$ & $1379.3 \mathrm{a}$ & $507.1 \mathrm{c}$ & $202.69 a$ \\
\hline BC $6.25 \mathrm{tha}^{-1}+\mathrm{RS} 6.25 \mathrm{tha}^{-1}+\mathrm{CF}$ & $3.79 \times 10^{8} \mathrm{a}$ & $5.82 \times 10^{10} \mathrm{a}$ & $4.5 \mathrm{~b}$ & $557.5 \mathrm{c}$ & $186.63 \mathrm{a}$ \\
\hline F-test & $* *$ & $*$ & $* *$ & $* *$ & $* *$ \\
\hline CV $(\%)$ & 36.16 & 45.70 & 20.15 & 29.96 & 15.75 \\
\hline
\end{tabular}

${ }^{1} \mathrm{CF}=$ chemical fertilizer, $\mathrm{BC}=$ biochar, $\mathrm{RS}=$ rice straw, $\mathrm{CV}=$ coefficient of variation. ${ }^{2} \mathrm{DOC}=$ dissolved organic carbon. The different small letters in the columns indicate significant difference among treatments by LSD. ${ }^{* * *}=$ significant at $p \leq 0.05$ and $p \leq 0.01, \mathrm{n}=4$.

In the soil treatments using RS alone, we observed high $\mathrm{CH}_{4}$ production and high archaeal abundance. The DOC content was supported by the significantly high positive correlation between archaeal abundance and $\mathrm{CH}_{4}$ production $(r=0.799 * * *)$ and the DOC concentration $(r=0.872 * * *)$. However, its moderately negative correlation with $\mathrm{CO}_{2}$ production $(r=-0.403)$ indicated that with an 
increasing abundance of archaea, the $\mathrm{CO}_{2}$ had been consumed (Figure 2a-c). Therefore, the archaea had performed a crucial role in $\mathrm{CH}_{4}$ production.
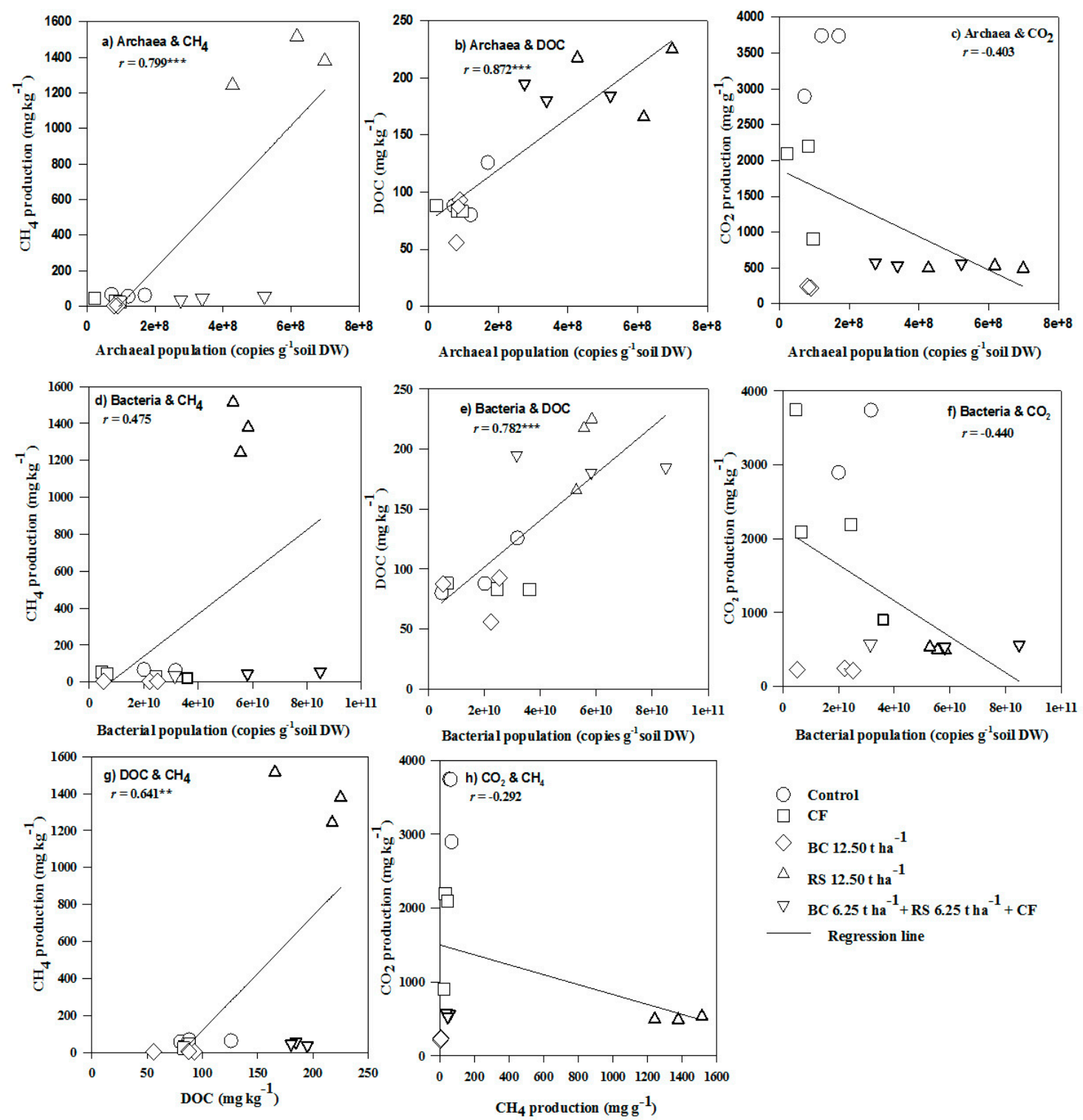

Figure 2. The correlation coefficients between Archaeal and $\mathrm{CH}_{4}$ production (a), DOC content (b) and $\mathrm{CO}_{2}$ production (c); between Bacterial abundance and $\mathrm{CH}_{4}$ production (d), DOC content $(\mathbf{e})$ and $\mathrm{CO}_{2}$ production (f); between DOC content and $\mathrm{CH}_{4}$ production $(\mathbf{g})$; and between $\mathrm{CH}_{4}$ and $\mathrm{CO}_{2}$ production (h). ${ }^{* *}$ Very significant at $p$-value $<0.01,{ }^{* * *}$ extremely significant at $p$-value $<0.001, \mathrm{n}=15$.

With respect to the bacteria, these appeared to be less effective in $\mathrm{CH}_{4}$ production compared to the archaea. This was reflected in the moderately positive correlation between bacterial abundance and $\mathrm{CH}_{4}$ production $(r=0.475)$ (Figure $2 \mathrm{~d}$ ), where the correlation between bacterial abundance and DOC concentration was significantly high $\left(r=0.782^{* * *}\right)$ (Figure 2e). This indicated that the bacteria had played a crucial role in supplying DOC to the soil system, thereby supporting $\mathrm{CH}_{4}$ production $\left(\mathrm{r}=0.641^{* *}\right)$ (Figure $2 \mathrm{~g}$ ). However, a moderately negative correlation between the bacterial abundance and $\mathrm{CO}_{2}$ production $(r=-0.440)$ indicated that $\mathrm{CO}_{2}$ had been consumed to form $\mathrm{CH}_{4}$ with the increasing abundance of bacteria (Figure $2 \mathrm{f}$ ). This assertion was supported by a weakly negative correlation coefficient of -0.292 between $\mathrm{CO}_{2}$ and $\mathrm{CH}_{4}$ production (Figure $2 \mathrm{~h}$ ). 
With respect to archaea exerting its effects on $\mathrm{CH}_{4}$ production, our results showed that compared to the bacteria, archaea was the more dominant microorganism. In the soil, especially in RS incorporated soil, Methanomicrobia was the main genus of archaea found, followed by Methanobacteria [22]. Moreover, in a previous pot experiment conducted with growing plants, the soil treated with RS showed a rapid decrease in soil redox potential to a range from -150 to $-200 \mathrm{mV}$ [1]. This was coupled with a rise in the soil $\mathrm{pH}$ to an optimal range of 7.5 to 8.5 . This observed phenomenon resulted from electrons transferred from the RS, which had been utilized by microorganisms in the anaerobic respiration process [1]. This condition was assumed to be suitable for methanogenic archaea and bacteria. Moreover, these results were found to be concomitant with the experimental results reported by Yuan et al. [22].

\subsection{Carbonaceous Greenhouse Gases and Microbial Abundance in Paddy Soil as Affected by BC}

In contrast to $\mathrm{RS}, \mathrm{BC}$ led to low levels of $\mathrm{CH}_{4}$ production in soils from both the pot experiments $\left(0.0233 \mathrm{mg} \mathrm{m}^{-2}\right.$ season $^{-1}$ ) (Table 3) and the incubation experiments $\left(45.7 \mathrm{mg} \mathrm{kg}^{-1}\right)$ (Table 4). This was because BC contained high levels of resistant $C$ compounds, such as lignin (75.69\%) and fixed C $(61.72 \%)$ (Table 1). We discovered that the resistant constituents of BC had suppressed the soil's $\mathrm{C}$ mineralization. Compared to the RS treated soil, this suppression had led to a significantly lower DOC content $\left(78.88 \mathrm{mg} \mathrm{kg}^{-1}\right)$, as well as lower archaeal abundance $\left(8.51 \times 10^{7}\right.$ copies g $^{-1}$ soil DW $)$ and bacterial abundance $\left(1.76 \times 10^{10}\right.$ copies $\mathrm{g}^{-1}$ soil DW) in the BC treated soil (Table 4$)$. This was consistent with a previous study by Liu et al, where it was found that paddy field soil amended with $\mathrm{BC}$ contributed to a low content of substrates [5]. In addition, the BC used in our experiments had a high content of VM (34.97\%) (Table 1), which consisted of DOC, such as carboxylics and phenolics (as determined using FTIR, Figure 1), as well as aldehydes [23]. Not only could the DOC be consumed for $\mathrm{CH}_{4}$ and $\mathrm{CO}_{2}$ production, but it could be used by soil microorganisms for assimilation into the MBC. However, the archaeal and bacterial abundances were similar between the $\mathrm{BC}$ treated soil and the control soil (Table 4) because the amounts of DOC in both soil treatments were low. The archaeal and bacterial abundances in the $\mathrm{BC}$ treated soil $\left(8.51 \times 10^{7}\right.$ and $1.76 \times 10^{10}$ copies $^{-1}$ soil DW, respectively) were significantly less than the abundances in RS treated soil $\left(5.81 \times 10^{8}\right.$ and $4.94 \times 10^{10}$ copies $^{-1}$ soil DW, respectively). These results confirmed a lower $\mathrm{CH}_{4}$ production in the $\mathrm{BC}$ treated soil (Table 4).

In terms of the microbial community, in the BC treated soil, a high MBC content of $224.08 \mathrm{mg}$ $\mathrm{kg}^{-1}$ (Table 3) revealed the good biological quality of the soil containing archaea, bacteria (Table 4), and methanotrophs [6], which were involved in the $\mathrm{CH}_{4}$ and $\mathrm{CO}_{2}$ dynamics of such soil. Wang et al. [4] reported that soil amended with BC had significantly altered the composition of the soil's archaeal and bacterial communities. Furthermore, it was reported that the main constituents of the archaea communities included a miscellaneous Crenarchaeota group (MCG), Methanobacteria, and Thaumarchaeota archaea. In our study, the BC treatments were likely to be comprised of archaea similar to the composition reported by Wang et al. [4].

Moreover, in the $\mathrm{BC}$ alone and combined $\mathrm{BC}+\mathrm{RS}+\mathrm{CF}$ treated soils, the $\mathrm{CH}_{4}$ production $(0.0233$ and $0.0235 \mathrm{mg} \mathrm{m}^{-2}$ season ${ }^{-1}$, respectively) was found to be lower than in the soils treated with RS treatments $\left(0.0347 \mathrm{mg} \mathrm{m}^{-2}\right.$ season $\left.{ }^{-1}\right)$. This may be attributed to the physical structure of $\mathrm{BC}$ given that it possessed several $\leq 2 \mathrm{~mm}$ micropores and had a large surface area [4,19], which could adsorb $\mathrm{CH}_{4}$ gas [5] and serve as a $\mathrm{CH}_{4}-\mathrm{C}$ substrate for the methanotrophs [6]. Biochar also supplied a habitat for the methanotrophs [6], where all these mechanisms had led to a reduction in $\mathrm{CH}_{4}$ production in the $\mathrm{BC}$ amended soil (Table 3).

\subsection{Carbonaceous Greenhouse Gases and Microbial Abundance in Paddy Soil as Affected by Combined BC and RS}

In the incubation experiments using the combined $\mathrm{BC}+\mathrm{RS}$ treatment $\left(\mathrm{BC} 6.25 \mathrm{t} \mathrm{ha}^{-1}+\right.$ RS $\left.6.25 \mathrm{t} \mathrm{ha}^{-1}+\mathrm{CF}\right)$, there was an abundance of archaea and bacteria $\left(3.79 \times 10^{8}\right.$ and $5.82 \times 10^{10}$ copies $\mathrm{g}^{-1}$ soil DW, respectively) (Table 4 ), which had proliferated at $6.25 \mathrm{tha}^{-1} \mathrm{RS}$ to yield $\mathrm{CH}_{4}$ of $4.5 \mathrm{mg} \mathrm{kg}^{-1}$ (Table 4). When the $\mathrm{CH}_{4}$ results of the combined treatment $\left(4.5 \mathrm{mg} \mathrm{CH}_{4} \mathrm{~kg}^{-1}\right)$ were 
compared to the results of the RS alone (12.50 tha $\left.{ }^{-1} \mathrm{RS}\right)\left(1379.3 \mathrm{mg} \mathrm{CH}_{4} \mathrm{~kg}^{-1}\right)$, we found that the $\mathrm{CH}_{4}$ had been drastically reduced in the combined treatment via the countering power of the $\mathrm{BC}$, probably through the $\mathrm{BC}$ inhibition of methanogenic activity [5] and the adsorption process of $\mathrm{BC}$. This result was despite the enhancing effects that $\mathrm{RS}$ had on $\mathrm{CH}_{4}$ production in such anaerobic soil through methanogenic archaea and bacteria activities (Table 4). On the contrary, the amount of $\mathrm{CO}_{2}$ production was found to be similar amongst the treatments of $\mathrm{BC}$, RS, or their combination in the incubated soils. The non-different "net" $\mathrm{CO}_{2}$ production was the net result of several microbial processes of microbial $\mathrm{C}$ mineralization $\left(\mathrm{CO}_{2}\right.$ production) and $\mathrm{CO}_{2}$ reduction $\left(\mathrm{CH}_{4}\right.$ formation) that occurred simultaneously, but to different degrees and directions in the soils treated with these studied amendments. Biochar applied alone resulted in a low $\mathrm{C}$ mineralization, rendering a low content of $\mathrm{CO}_{2}$ (Table 4). In contrast, RS alone favored $\mathrm{C}$ mineralization to form $\mathrm{CO}_{2}$, which was furthered reduced to $\mathrm{CH}_{4}$ and resulted in low $\mathrm{CO}_{2}$ in the RS treated soil. In the combined $\mathrm{BC}+\mathrm{RS}$ soil, the adverse effect of $\mathrm{BC}$ on RS resulted in a low $\mathrm{CO}_{2}$ (Table 4). In the combined $\mathrm{BC}+\mathrm{RS}+\mathrm{CF}$ soil, $\mathrm{CH}_{4}$ production in the potted soil $\left(0.0235 \mathrm{mg} \mathrm{m}^{-2}\right.$ season $\left.^{-1}\right)$ was significantly lower than in the $\mathrm{RS}$ alone $\left(0.0347 \mathrm{mg} \mathrm{m}^{-2}\right.$ season $\left.^{-1}\right)$ (Table 3). It appeared that the results for $\mathrm{CH}_{4}$ production from the incubation experiments and rice pot experiments behaved in the same manner. However, conditions in the potted soil planted with rice differed from the conditions in the incubated soil, i.e., in the rice pot experiment, there were $\mathrm{C}$ substrates derived from rhizodeposition (root exudates, sloughed root, and dead root) [24], large areas of aerobic and anaerobic interface in the rice rhizosphere soil, and an oxidizing layer on the soil surface, whereas the incubated soil was presumably completely anaerobic. The BC-enhanced microbiological oxidation process was mediated by methanotrophs, which consumed $\mathrm{CH}_{4}$ and transformed it into $\mathrm{CO}_{2}$ at the aerobic-anaerobic interface [25] of the rice rhizosphere and the submerged soil. Therefore, as a consequence, $\mathrm{CO}_{2}$ was released into the atmosphere (Table 3). This process is expected to exist within the rice rhizosphere at the aerobic-anaerobic interface, and it results in decreases in $\mathrm{CH}_{4}$ and the release of $\mathrm{CO}_{2}$ to the soil. More than $90 \%$ of the $\mathrm{CH}_{4}$ production in soil is oxidized to $\mathrm{CO}_{2}$ [6]. Our findings from the rice which had been planted in potted soil, enabled us to articulate the countering effects of the $\mathrm{BC}$ amendments on $\mathrm{CH}_{4}$ production in soil via two possible mechanisms. These included the adsorption of $\mathrm{CH}_{4}$ onto the $\mathrm{BC}$ surfaces and the oxidation of $\mathrm{CH}_{4}$ to $\mathrm{CO}_{2}$ by methanotrophs which utilize $\mathrm{CH}_{4}$ as a source of $\mathrm{C}$ and energy [6].

The rice grain yields obtained from the combined treatment $\left(\mathrm{BC} 6.25 \mathrm{tha}^{-1}+\mathrm{RS} 6.25 \mathrm{tha}^{-1}+\mathrm{CF}\right)$ and individual CF treatment were 53.47 and $50.62 \mathrm{~g} \mathrm{pot}^{-1}$, respectively (Table 3), being the two highest yields in our pot experiments. In contrast, $\mathrm{BC}$ alone and $\mathrm{RS}$ alone depressed rice yields. It could be deduced that the enhanced yield under the combined BC + RS + CF treatment was due to the CF effect on grain yield. With $\mathrm{CFs}$ favorable supply of nutrients and the high nutrient adsorption characteristics of $B C$, the combined $B C+R S+C F$ treatment could supply and retain sufficient plant nutrients for rice growth. In addition, chlorosis was observed in the rice plants treated with $\mathrm{BC}$ or RS alone. The studied soil had a low $\mathrm{N}$ content $(0.08 \%)$ which caused soil $\mathrm{N}$ deficiency and led to a low rice yield. Therefore, $\mathrm{CF}$ is a necessary supplement for the amendment of organic materials in the soil.

\section{Conclusions}

Our results proved our hypothesis, that is, the incorporation of a combination of BC and RS in paddy soil reduces the soil's $\mathrm{CH}_{4}$ production, raises archaeal and bacterial abundances, and increases the yield of rice grains compared to unamended soil. With such a combined BC + RS soil amendment, the RS component (a cellulose and hemicellulose-rich material) was able to rapidly decompose and enhance the archaeal and bacterial abundances relative to the without-RS amendments. Concurrently, in the combined $\mathrm{BC}+\mathrm{RS}$, there was a rapid production of the intermediate products of decomposition (i.e., $\mathrm{DOC}, \mathrm{CO}_{2}$, and $\mathrm{H}_{2}$ ) which served as substrates for microbes to produce $\mathrm{CH}_{4}$ in the methanogenesis process. Conversely, the recalcitrant lignin-rich $\mathrm{BC}$ component of the combined $\mathrm{BC}+\mathrm{RS}$ amendment inhibited the activity of the archaea in methanogenesis resulting in lower $\mathrm{CH}_{4}$ production than that of the RS alone. One of the proposed mechanisms for the suppression of methanogenesis was a high 
abundance of methanotrophic bacteria in the $\mathrm{BC}$, which served as the bacteria's habitat. Methanotrophs performed the $\mathrm{CH}_{4}$ oxidation process, which reduced the $\mathrm{CH}_{4}$ content. Another mechanism was the adsorption of $\mathrm{CH}_{4}$ onto the large and highly adsorptive surface area of the $\mathrm{BC}$, which led to $\mathrm{CH}_{4}$ reduction in the combined $\mathrm{BC}+\mathrm{RS}$ treated soil. Compared to paddies receiving $\mathrm{RS}$ or $\mathrm{BC}$ applied individually, a further benefit was the high rice grain yield under the combined $\mathrm{BC}+\mathrm{RS}$ treatment. The combined BC + RS material proved to be a more beneficial soil amendment than the RS or BC applied separately owing to the dual purposes of improving soil productivity and reducing greenhouse gas emissions.

Author Contributions: Conceptualization, S.K., P.S., and P.L.; Methodology, P.S. and P.L.; Formal analysis, S.K., P.S., and P.L.; Resources, P.S. and P.L.; Software, S.K.; Data curation, P.S. and P.L.; Writing-Original Draft Preparation, S.K., P.S., and P.L.; Writing-Review and Editing, S.K., P.S., P.V., and P.L.; Supervision, P.S. and P.L., Validation, S.K. and P.L.; Project Administration, S.K., P.S., and P.L.; Funding Acquisition, P.S., P.V., and P.L.

Funding: This research was funded by the Soil Organic Matter Management Research Group of Khon Kaen University (KKU) and the Thesis Support Scholarship from the Graduate School of KKU.

Acknowledgments: Special thanks to Khon Kaen University for providing the facilities used to conduct the experiments. Acknowledgement is extended to the Soil Organic Matter Management Research Group of Khon Kaen University (KKU) for providing financial support, and the first author was provided with a Thesis Support Scholarship from the Graduate School of KKU.

Conflicts of Interest: The authors declare no conflict of interest. The funding sponsors had no role in the design of the study; in the collection, analyses, or interpretation of data; in the writing of the manuscript, and in the decision to publish the results.

\section{References}

1. Thammasom, N.; Vityakon, P.; Saenjan, P. Response of methane emissions, redox potential, and $\mathrm{pH}$ to eucalyptus biochar and rice straw addition in a paddy soil. Songklanakarin J. Sci. Technol. 2016, 38, 325-331.

2. Chowdhury, T.R.; Dick, R.P. Ecology of aerobic methanotrophs in controlling methane fluxes from wetlands. Appl. Soil Ecol. 2013, 65, 8-22. [CrossRef]

3. Thammasom, N.; Vityakon, P.; Lawongsa, P.; Saenjan, P. Biochar and rice straw have different effects on soil productivity, greenhouse gas emission and carbon sequestration in Northeast Thailand paddy soil. Agric. Nat. Resour. 2016, 50, 192-198. [CrossRef]

4. Wang, N.; Chang, Z.; Xue, X.; Yu, J.; Shi, X.; Ma, L.Q.; Li, H. Biochar decreases nitrogen oxide and enhances methane emissions via altering microbial community composition of anaerobic paddy soil. Sci. Total Environ. 2017, 689-696. [CrossRef]

5. Liu, Y.; Yang, M.; Wu, Y.; Wang, H.; Chen, Y.; Wu, W. Reducing $\mathrm{CH}_{4}$ and $\mathrm{CO}_{2}$ emissions from waterlogged paddy soil with biochar. J Soils Sediments. 2011, 11, 930-939. [CrossRef]

6. Feng, Y.; Xu, Y.; Yu, Y.; Xie, Z.; Lin, X. Mechanisms of biochar decreasing methane emission from Chinese paddy soils. Soil Biol. Biochem. 2012, 46, 80-88. [CrossRef]

7. Bremner, J.M. Total nitrogen. In Method of Soil Analysis. Part 2; Black, C.A., Ed.; American Society of Agronomy: Madison, WI, USA, 1965; pp. 1149-1178.

8. Aravantinos-Zafiris, G.; Oreopoulou, V.; Tzia, C.; Thomopoulos, C.D. Fiber fraction from orange peel residues after pectin extraction. LWT-Food Sci. Technol. 1994, 27, 468-471. [CrossRef]

9. American Standard Test Method International. Standard Test. Method for Chemical Analysis of Wood Charcoal; ASTM International Destination: Pennsylvania, PA, USA, 2007; pp. D1762-D1784.

10. Coates, J. Interpretation of Infrared Spectra, A practical Approach. In Encyclopedia of Analytical Chemistry.; Meyers, R.A., Ed.; John Wiley \& Sons Ltd: Chichester, UK, 2000; pp. 10815-10837.

11. Daffalla, S.B.; Mukhtar, H. and Shaharun, M.S. Characterization of Adsorbent Developed from Rice Husk: Effect of Surface Functional Group on Phenol Adsorption. Appl. Sci. 2010, 10, 1060-1067.

12. Bouyoucos, G.J. Directions for making mechanical analysis of soils by the hydrometer method. Soil Sci. 1936, 4, 225-228. [CrossRef]

13. Walkley, A.; Black, J.A. An examination of the dichormate method for determining soil organic matter and a proposed modification of the chromic acid titration method. Soil Sci. 1934, 37, 29-38. [CrossRef] 
14. Vance, E.D.; Brookes, P.C.; Jenkinson, D.S. An extraction method for measuring microbial biomass C. Soil Biol. Biochem. 1987, 22, 703-707. [CrossRef]

15. Saenjan, P.; Tulaphitak, D.; Tulaphitak, T.; Soupachai, T.; Suwat, J. Methane emission from Thai farmers'paddy fields as a basis for appropiate mitigation technologies. In Proceedings of the 17th World Congress of Soil Science, Bangkok, Thailand, 14-21 August 2002.

16. Lane, D. 16S/23S rRNA sequencing. In Nucleic Acid Techniques Systematics; Stackebrandt, A., Goodfellow, M., Eds.; John Wiley: West Sussex, UK, 1991; pp. 115-175.

17. Muyzer, G.; De Waal, E.C.; Uitterlinden, A.G. Profiling of complex microbial populations by denaturing gradient gel electrophoresis analysis of polymerase chain reaction-amplified genes coding for 16S rRNA. Appl. Environ. Microbiol. 1993, 59, 695-700. [PubMed]

18. Lueders, T.; Friedrich, M. Archaeal population dynamics during sequential reduction processes in rice field soil. Appl. Environ. Microbiol. 2000, 66, 2732-2742. [CrossRef] [PubMed]

19. Gonetl, S.S.; Debska, B. Dissolved organic carbon and dissolved nitrogen in soil under different fertilization treatments. Plant Soil Eviron. 2006, 52, 55-63. [CrossRef]

20. Kunlanit, B. Decomposition of biochemistry contrasting organic residues regulating dissolved organic carbon dynamics and soil organic carbon composition in a sandy soil. Ph.D. Thesis, Khon Kaen University, Khon Kaen, Thailand, December 2014.

21. Lehmann, J.; Rilling, M.C.; Thies, J.; Masiello, A.C.; Hockaday, C.W.; Crowley, D. Biochar effects on soil biota-A review. Soil Biol. Biochem. 2011, 43, 1812-1836. [CrossRef]

22. Yuan, Q.; Hernandez, M.; Dumont, M.G.; Rui, J.; Fernandez Scavino, A.; Conrad, R. Soil bacterial community mediates the effect of plant material on methanogenic decomposition of soil organic matter. Soil Biol. Biochem. 2018, 116, 99-109. [CrossRef]

23. Butnan, S.; Deenik, J.L.; Toomsan, B.; Antal, M.J.; Vityakon, P. Biochar characteristics and application rates affecting corn growth and properties of soils contrasting in texture and mineralogy. Geoderma. 2015, 105-116. [CrossRef]

24. Aulakh, M.S.; Wassmann, R.; Bueno, C.; Kreuzwieser, J.; Rennenberg, H. Characterization of Root Exudates at Different Growth Stages of Ten Rice (Oryza sativa L.) Cultivars. Plant Biol. 2001, 3, 139-148. [CrossRef]

25. Cao, M.; Gregson, K.; Marshall, S.; Dent, J.B.; Heal, O.W. Global methane emissions from rice paddies. Chemosphere 1996, 33, 879-897. [CrossRef] 